\title{
Response of live mulches and weed management practices on nutrient uptake by crop and nutrient depletion by weed under direct seeded rice
}

\author{
Lovejeet Singh and Santosh Kumar* \\ Department of Agriculture, Mata Gujri College, Fatehgarh Sahib, Punjabi University, Patiala, Punjab- 140406 \\ *Correspondence: santoshagro.nd@gmail.com,
}

Received: 25 April 2020 /Accepted: 18 June 2020

URL: https://doi.org/10.38112/agw.2020.v08i01.003

\begin{abstract}
A field experiment was conducted at Experimental Farm, Department of Agriculture, Mata Gujri College, Fatehgarh Sahib, Punjab during rainy season of 2017 to evaluate the response of live mulches and weed management practices on nutrient update by crop and nutrient depletion by weed under direct seeded rice. The results indicated that the maximum nutrient update by crop was recorded under live mulch with sesbania, which was statistically at par with live mulch with lobia and significantly superior over live mulch with sesamum. However, the maximum nutrient update by crop was recorded with application of bispyricbac-Na @ 25.0 g/ha + carfentrazone @ $20.0 \mathrm{~g} / \mathrm{ha}$ and found at par to bispyricbac- $\mathrm{Na} @ 25.0 \mathrm{~g} / \mathrm{ha}+$ ethoxysulfuron @ $18.0 \mathrm{~g} / \mathrm{ha}$, which was significantly superior over other treatments. The minimum weed depletion was recorded under live mulch with sesbania followed by live mulch with lobia and sesamum. However, the minimum weed depletion was recorded was recorded with application of bispyricbac-Na @ $25.0 \mathrm{~g} / \mathrm{ha}$ + carfentrazone @ $20.0 \mathrm{~g} / \mathrm{ha}$ and found at par all herbicides treatments which were significantly inferior over weedy check.
\end{abstract}

Key words: Live mulch, Nutrient depletion, Nutrient uptake, Sesamum and Sesbania.

\section{Introduction}

Rice (Oryza sativa L.) is predominant crop of Punjab. It is the most important staple food of the world population. Transplanting is the most common method for cultivation of paddy in not only Punjab but in Asia. It requires more water and labour for the pudlling and transplanting of crop (Kumar and Ladha, 2011). Puddling not only destroyed soil properties but also more methane emission and water depletion. Under this situation, direct seeding of rice (DSR) seems a viable alternative in rescuing farmers (Farooqet al. 2011). Dry direct seeding with pre-germinated seed is totally unexplored as it could be an effective option to combat the problems like delay in sowing of succeeding crop, low system productivity, poor performance of direct seeding of rice if the weeds are controlled effectively as it becomes a major constraint in dry direct seeded rice ecosystem. Weeds are mostly removed from the rice field manually in traditional method of rice cultivation. High weed infestation is a major problem in direct-seeded rice and causes yield Materials and Methods

A field experiment was conducted at Experimental Farm, Department of Agriculture, Mata Gujri College, Fatehgarh Sahib (Punjab), during Kharif season of 2017. The soil was alluvial having clay loam in texture losses up to $90 \%$ (Rehman et al. 2007). He further reported that the lower broad-leaved weed density and dry weight were observed with Sesbania and other brown manuring species than the surface mulch. Intercropping of brown manuring crops with rice reduced weed densities by about $40-50 \%$. The aerobic soil conditions and dry-tillage practices, besides alternate wetting and drying conditions, are conducive for germination and growth of highly competitive weeds, which cause grain yield losses of $50-91 \%$ (Chauhan and Johnson, 2011). The low crop productivity because of moisture stress and heavy weed infestation aggravate food and nutritional insecurity of the region (Das et al. 2015). Preemergence herbicides in combination with postemergence herbicides are needed to control weeds in direct seeded rice because of diverse weed flora. Kumar and Singh, 2016 reported that application of pendimethalin $1.0 \mathrm{~kg} / \mathrm{ha}$ fbbispyribac + carfentrazone $(25+20 \mathrm{~g} / \mathrm{ha})$ was more efficient to minimizing weed the nutrient depletion by weed.

with normal soil reaction (7.90), low organic carbon $(0.62 \%)$, medium available $\mathrm{N}(280.15 \mathrm{~kg} / \mathrm{ha})$, and medium in available $\mathrm{P}_{2} \mathrm{O}_{5}(30.84 \mathrm{~kg} / \mathrm{ha})$ and low available $\mathrm{K}_{2} \mathrm{O}(130.84 \mathrm{~kg} / \mathrm{ha})$. The experiment was laid out in split-plot design with three live mulch and six weed management practices and replicated three 
times. The live mulch was subjected to main plots, viz. live mulch with sesbania, lobia and sesamum and weed management was applied in sub plots, viz. weedy free, weed check, pendimethalin @ $1.0 \mathrm{~kg} / \mathrm{ha}$ (PE)fbbispyricbac- $\quad \mathrm{Na} \quad @ \quad 25.0 \quad \mathrm{~g} / \mathrm{ha} \quad$ (POE), bispyricbac-Na@25.0 g/ha +carfentrazone @ 20.0 g/ha (POE), bispyricbac- Na @ 25.0 g/ha + ethoxysulfuron@18.0 g/ha (POE) and pendimethalin @ $1.0 \mathrm{~kg} / \mathrm{ha}$ (PE). Sowing was done manually with the help of kudal. Rice variety PR 126 was seeded directly in moist soil using $30 \mathrm{~kg}$ seed ha ${ }^{-1}$ in rows spaced at 20 $\mathrm{cm}$ with single row seed drill on $12^{\text {th }}$ June 2017. Sesbania, Lobia and sesamumwas broadcasted in soil using 50, 40 and $4 \mathrm{~kg}$ respectively seed $\mathrm{ha}^{-1}$ after sowing of rice. Recommended dose of $\mathrm{N}, \mathrm{P}_{2} \mathrm{O}_{5}$ and $\mathrm{K}_{2} \mathrm{O}$ were applied at 120,60 and $40 \mathrm{~kg} / \mathrm{ha}$ respectively. Half of total nitrogen and full dose of phosphorus, and potassium were applied to rice crop as basal application before sowing. Remaining half dose of nitrogen in the form of urea was top dressed in two equal splits, at active tillering and panicle initiation stage during the period. Weed control treatments were applied in the plots as per the experimental treatments. Live mulches were sown between rows of rice just after sowing of rice crop. Nutrient uptake by grain and straw of rice crop was calculated by multiplying yields of grain or straw with its nutrient contents. Nutrient (N, P and K) depletion by weeds was calculated by multiplying accumulation of weed dry matter with its nutrient contents.

\section{Result and Discussion}

\section{Effect on N, P and $K$ content (\%)}

The data related to $\mathrm{N}, \mathrm{P}$ and $\mathrm{K}$ content $(\%)$ in grain and straw did not influenced significantly due to application of live mulches and weed management practices presented in (Table 1). The data shows that the application of mulching application at live mulch with sesbania recorded maximum nitrogen content in grain and straw followed by live mulch with lobia and sesamum during experimentation. This might be due to there are no direct role in accumulation of nutrient in crop. The all live mulches only suppress the weed density and production of weed dry matter (Maity and Mukherjee, 2011). Among weed management treatments, the maximum nutrient content in grain and straw was recorded under application of bispyricbac$\mathrm{Na} @ 25.0 \mathrm{~g} \mathrm{ha}^{-1}+$ carfentrazone @ $20.0 \mathrm{~g} \mathrm{ha}^{-1}$ followed by bispyricbac $\mathrm{Na} @ 25.0 \mathrm{~g}$ ha $^{-}$ ${ }^{1}+$ ethoxysulfuron@18.0 $\mathrm{g} \mathrm{ha}^{-1}$. However, all the sequential application of herbicides had higher nutrient content over weedy check which had lowest nutrient content during experiment (Table 1). This due to all herbicides treatments control weeds at timely and also reduces the nutrient depletion by weed. The similar result also reported by Rehman2007; Kumar and Singh, 2016.

\section{Effect on total N, P and K uptake ( $\left.\mathrm{kg} \mathrm{ha}^{-1}\right)$}

The total nutrient uptake was significantly influenced by live mulch and weed management treatments (Table 2,3). The results shows that live mulch with sesbania recorded significantly higher total $\mathrm{N}, \mathrm{P}$ and $\mathrm{K}$ uptake and minimum recorded with live mulch with sesamum. It was found on par to live mulch with lobia during experimentation. This might be due to the sesbania and lobia both legume crops that fix the nitrogen into the soil. It helps improve nutrient contents, minimized nutrient losses through weeds. The live mulch with legume crops increase the fertilizer use efficiency and improve nutrient content and their uptake (Maityet al. 2009) and (Gill \&Walia, 2014). Amongst weed management treatments, highest total N, P and K uptake by crop was associated with weed free treatment which was significantly superior to all herbicidal treatments. In weed management practices, total $\mathrm{N}, \mathrm{P}$ and $\mathrm{K}$ uptake recorded under bispyricbac-Na @ $25.0 \mathrm{~g}$ ha $^{-}$ ${ }^{1}+$ carfentrazone @ $20.0 \mathrm{~g} \mathrm{ha}^{-1}$ which was significantly superior to alone application of pendimethaline@1.0 $\mathrm{kg} \mathrm{ha}{ }^{-1}+$ bispyricbac $\mathrm{Na} @ 25.0 \mathrm{~g} \mathrm{ha}^{-1}$ and pendimethalin@1.0 $\mathrm{kg} \mathrm{ha}^{-1}$. However, it was found at par to bispyricbac- Na@25.0 $\mathrm{g} \mathrm{ha}^{-1}+$ ethoxysulfuron @ $18.0 \mathrm{~g} \mathrm{ha}^{-1}$ during experimentation (Table 2). This might be due to lower nutrient depletion by weeds in these treatments. Hence, it appears that competition for nutrients was more serious in presence of luxuriant weed growth in weedy check which resulted in less availability and uptake by crop and the lowest uptake of nutrients (NPK) by crop were recorded under weedy check. The similar result were finding by Sharma (2007) and Chaudharyet al. (2011).

\section{Nutrient depletion by weed $\left(\mathrm{kg} \mathrm{ha}^{-1}\right)$}

The data pertaining to nutrient depletion by weeds as influenced by live mulch and weed management treatments at 60 DAS (Table 3). Analysis of data revealed that live mulch caused variation in nutrient depletion by weeds during crop growth. The minimum nutrient depletion was recorded by mulching application live mulch with sesbania followed by live mulch with cowpea. Data also showed that mulching application live mulch with sesamum had maximum nutrient depletion by weeds during experimentation. The results showed that application of bispyricbac-Na @ $25.0 \mathrm{~g} \mathrm{ha}^{-1}+$ carfentrazone @ $20.0 \mathrm{~g} \mathrm{ha}^{-1}$ was most efficient in reducing nutrient depletion by weeds and had significantly lower nutrient depletion by weeds 
than weedy check and it also found at par with all herbicides treatment during crop growth. It due to these treatments helps in reducing the weed density and its dry matter. The weed dry matter under this treatment and nutrient depletion is known to be positively correlated with weed dry matter accumulation. This is in agreement with the findings of Singh et al. (2013) and Kumar \& Singh, 2016.

\section{Conclusion}

This study shows that the application of live mulch of sesbania with combination of bispyricbac-Na @ $25.0 \mathrm{~g} \mathrm{ha}^{-1}+$ carfentrazone @ $20.0 \mathrm{~g} \mathrm{ha}^{-1}$ was most efficient in reducing nutrient depletion by weeds and higher nutrient uptake by crop in direct seeded rice under irrigated conditions in central Punjab.

\section{References}

Chaudhary SK, Jha S and Sinha NK. 2011. Influence of nitrogen and weed management practices on productivity and nutrient uptake of wet direct seeded rice. Oryza 48(3):222-225.

Chauhan B S and Johnson D E. 2009. Influence of tillage systems on weed seedling emergence pattern in rainfed rice. Soil Tillage Research 106:15-21.

Das A, Ramkrushna GI, Yadav GS, Layek J, Debnath C, Choudhury BU, Mohaptara KP, Ngachan SV, Das S. 2015. Capturing traditional practices of rice-based farming systems and identifying interventions for resource conservation and food security in Tripura, India. Applied Ecology Environmental Science 3(4):100-107.

Farooq M, Siddique KHM, Rehman H, Aziz T, Wahid $A$ and Lee D. 2011. Rice direct seeding experiences and challenges. Soil Tillage Research 111: 87-98.

Gill JS and Walia SS. 2014. Influence of FYM, brown manuring and nitrogen levels on direct seeded and transplanted rice (Oryza sativa L.). Research Journal Agriculture Environment Management 3:417-26.

Kumar S and Singh RK. 2016. Interaction effect of nitrogen schedule and weed management on weeds, nutrient depletion and yield of direct seeded rice. Indian Journal of Weed Science 48(4): 372377.

Kumar V and Ladha JK. 2011. Recent developments in direct-seeding of rice. Advances in Agronomy 111:297-413.

Maity SK and Mukherjee, PK. 2011. Effect of brown manuring on grain yield and nutrient use efficiency in dry direct seeded kharif rice (Oryza sativa 1.). Indian Journal of Weed Science 43(1-2):61-66.
Maity SK and Mukherjee PK. 2009. Integrated weed management practices in dry direct-seeded summer rice (Oryza sativa). Indian Journal of Agricultural Sciences 79(12):976-979.

Rehman HM Farooq and A Khalid. 2007. Managing weeds in direct seeded rice. DAWN group of newspaper .2007. http.//DAWN.com.

Sarangi DR, Sahoo TR, Sethy S, Chourasia M, Prasad SM, Mohanta RK and Sadangi BN. 2016. Effect of replacing a part of nitrogenous fertilizer by brown manuring in direct seeded rice: a field study. Oryza 53(2):226-228.

Sharma RP. 2007. Dry matter accumulation and nitrogen uptake pattern in direct seeded upland rain fed rice as influenced by nitrogen and weed management practices. Journal of Farming Research \& Development 13(2):191-197.

Singh A, Singh RK, Kumar P and Singh S. 2013. Growth, weed control and yield of DSR as influenced by different herbicides. Indian Journal of Weed Science 45(4):235-238. 
Table 1: Effect of live mulch and weed management on N P K content (\%) in grain and straw

\begin{tabular}{|c|c|c|c|c|c|c|}
\hline Treatment & $\begin{array}{l}\mathrm{N} \text { content in } \\
\text { grain }(\%)\end{array}$ & $\begin{array}{l}\mathrm{N} \text { content in } \\
\text { straw }(\%)\end{array}$ & $\begin{array}{l}\mathrm{P} \text { content in } \\
\text { grain }(\%)\end{array}$ & $\begin{array}{l}\mathrm{P} \text { content in } \\
\text { straw }(\%)\end{array}$ & $\begin{array}{l}\mathrm{K} \text { content in } \\
\text { grain }(\%)\end{array}$ & $\begin{array}{l}\mathrm{K} \text { content in } \\
\text { straw }(\%)\end{array}$ \\
\hline \multicolumn{7}{|l|}{ Live mulches } \\
\hline Live mulch with sesbania & 2.08 & 0.47 & 0.43 & 0.06 & 0.51 & 1.56 \\
\hline Live mulch with lobia & 2.06 & 0.44 & 0.43 & 0.06 & 0.50 & 1.55 \\
\hline Live mulch with sesamum & 2.03 & 0.43 & 0.42 & 0.06 & 0.49 & 1.53 \\
\hline $\mathrm{SEm} \pm$ & 0.01 & 0.01 & 0.00 & 0.00 & 0.00 & 0.01 \\
\hline $\mathrm{CD}(\mathrm{P}=0.05)$ & NS & NS & NS & NS & NS & NS \\
\hline \multicolumn{7}{|l|}{ Weed management practices } \\
\hline Weed free & 2.25 & 0.55 & 0.52 & 0.07 & 0.63 & 1.81 \\
\hline Weed check & 1.41 & 0.35 & 0.29 & 0.03 & 0.34 & 1.16 \\
\hline $\begin{array}{l}\text { Pendimethaline @ } 1.0 \mathrm{~kg} \mathrm{ha}^{-1} f b \text { Bispyricbac- } \\
\mathrm{Na} @ 25.0 \mathrm{~g} \mathrm{ha}^{-1}\end{array}$ & 2.14 & 0.44 & 0.41 & 0.05 & 0.45 & 1.45 \\
\hline $\begin{array}{l}\text { Bispyricbac-Na @ } 25.0 \mathrm{~g} \mathrm{ha}^{-1} f b \text { Carfentrazone } \\
\text { @ } 20.0 \mathrm{~g} \mathrm{ha}^{-1}\end{array}$ & 2.20 & 0.47 & 0.47 & 0.07 & 0.57 & 1.73 \\
\hline $\begin{array}{l}\text { Bispyricbac-Na@25.0 g ha- } \\
{ }^{1} f b \text { Ethoxysulfuron @18.0 } \mathrm{g} \mathrm{ha}^{-1}\end{array}$ & 2.19 & 0.46 & 0.46 & 0.07 & 0.55 & 1.71 \\
\hline Pendimethalin@1.0 kg ha ${ }^{-1}$ & 2.14 & 0.41 & 0.40 & 0.05 & 0.44 & 1.44 \\
\hline $\mathrm{SEm} \pm$ & 0.01 & 0.01 & 0.00 & 0.00 & 0.00 & 0.01 \\
\hline $\mathrm{CD}(\mathrm{P}=0.05)$ & NS & NS & NS & NS & NS & NS \\
\hline
\end{tabular}


Singh and Kumar

Table 2: Effect of live mulch and weed management on NPK uptake by grain and straw $\left(\mathrm{kg} \mathrm{ha}^{-1}\right)$

\begin{tabular}{|c|c|c|c|c|c|c|}
\hline Treatment & $\begin{array}{c}\text { N uptake by } \\
\text { grain } \\
\left.\text { ha }^{-1}\right)\end{array}$ & 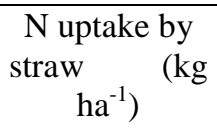 & 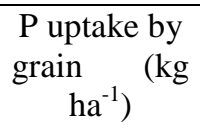 & $\begin{array}{c}\text { P uptake by } \\
\text { straw } \\
\left.\text { ha }^{-1}\right)\end{array}$ & $\begin{array}{l}\text { K uptake by } \\
\text { grain } \\
\left.\text { ha }^{-1}\right)\end{array}$ & $\begin{array}{c}\text { K uptake by } \\
\text { straw } \\
\left.\text { ha }^{-1}\right)\end{array}$ \\
\hline \multicolumn{7}{|l|}{ Live mulches } \\
\hline Live mulch with sesbania & 101.98 & 31.74 & 21.52 & 4.10 & 25.19 & 107.05 \\
\hline Live mulch with lobia & 98.21 & 29.45 & 20.59 & 3.87 & 24.14 & 102.84 \\
\hline Live mulch with sesamum & 92.69 & 27.11 & 19.11 & 3.58 & 22.52 & 96.22 \\
\hline $\mathrm{SEm} \pm$ & 1.03 & 0.33 & 0.26 & 0.05 & 0.30 & 1.47 \\
\hline $\mathrm{CD}(\mathrm{P}=0.05)$ & 1.04 & 1.30 & 1.03 & 0.19 & 1.19 & 5.75 \\
\hline \multicolumn{7}{|l|}{ Weed management practices } \\
\hline Weed free & 130.91 & 40.34 & 30.07 & 5.51 & 36.56 & 133.16 \\
\hline Weed check & 37.74 & 16.86 & 7.86 & 1.59 & 9.02 & 55.47 \\
\hline $\begin{array}{l}\text { Pendimethaline @ } 1.0 \mathrm{~kg} \mathrm{ha}^{-1} f b \text { Bispyricbac- } \\
\mathrm{Na} @ 25.0 \mathrm{~g} \mathrm{ha}^{-1}\end{array}$ & 92.49 & 27.29 & 17.74 & 3.39 & 19.36 & 90.69 \\
\hline $\begin{array}{l}\text { Bispyricbac-Na @25.0 g ha }{ }^{-1} f b \text { Carfentrazone } \\
\text { @ } 20.0 \mathrm{~g} \mathrm{ha}^{-1}\end{array}$ & 118.22 & 34.24 & 25.29 & 4.80 & 30.66 & 124.54 \\
\hline $\begin{array}{l}\text { Bispyricbac-Na @ 25.0 g ha- } \\
{ }^{1} f b \text { Ethoxysulfuron @ } 18.0 \mathrm{~g} \mathrm{ha}^{-1}\end{array}$ & 118.51 & 33.10 & 24.85 & 4.68 & 30.05 & 121.50 \\
\hline Pendimethalin@1.0 $\mathrm{kg} \mathrm{ha}^{-1}$ & 87.89 & 24.76 & 16.63 & 3.12 & 18.05 & 86.85 \\
\hline SEm \pm & 3.56 & 0.96 & 0.93 & 0.11 & 1.05 & 2.34 \\
\hline $\mathrm{CD}(\mathrm{P}=0.05)$ & 10.29 & 2.78 & 2.68 & 0.31 & 3.02 & 6.76 \\
\hline
\end{tabular}


Table 3: Effect of live mulch and weed management on total uptake of NPK $\left(\mathrm{kg} \mathrm{ha}^{-1}\right)$ and nutrient depletion by weed

\begin{tabular}{|c|c|c|c|c|c|c|c|}
\hline Treatment & $\begin{array}{c}\text { Total N } \\
\text { uptake } \\
\left(\mathrm{kg} \mathrm{ha}^{-1}\right)\end{array}$ & $\begin{array}{l}\text { Total P } \\
\text { uptake } \\
\left(\mathrm{kg} \mathrm{ha}^{-1}\right)\end{array}$ & $\begin{array}{c}\text { Total K } \\
\text { uptake } \\
\left(\mathrm{kg} \mathrm{ha}^{-1}\right)\end{array}$ & $\begin{array}{c}\text { Weed dry } \\
\text { weight }\left(\mathrm{g} / \mathrm{m}^{2}\right)\end{array}$ & $\begin{array}{c}\text { N uptake by } \\
\text { weed (kg ha } \\
1 \\
1\end{array}$ & $\begin{array}{c}\text { P uptake by } \\
\text { weed }(\mathrm{kg} \\
\left.\mathrm{ha}^{-1}\right)\end{array}$ & $\begin{array}{c}\text { K uptake by } \\
\text { weed } \\
\left(\mathrm{kg} \mathrm{ha}^{-1}\right)\end{array}$ \\
\hline \multicolumn{8}{|l|}{ Live mulches } \\
\hline Live mulch with sesbania & 133.72 & 25.62 & 132.2 & $10.38(122.20)$ & 3.48 & 2.10 & 3.79 \\
\hline Live mulch with lobia & 127.66 & 24.45 & 127.0 & $10.79(125.10)$ & 4.22 & 2.12 & 4.14 \\
\hline Live mulch with sesamum & 119.80 & 22.69 & 118.7 & $11.06(129.70)$ & 5.06 & 2.27 & 4.61 \\
\hline SEm \pm & 1.08 & 0.30 & 1.7 & 0.11 & 0.39 & 0.04 & 0.26 \\
\hline $\mathrm{CD}(\mathrm{P}=0.05)$ & 4.22 & 1.18 & 6.6 & 0.43 & NS & NS & NS \\
\hline \multicolumn{8}{|l|}{ Weed management practices } \\
\hline Weed free & 171.25 & 35.59 & 169.7 & $\begin{array}{c}0.71 \\
(0.00)\end{array}$ & 0.00 & 0.00 & 0.00 \\
\hline Weed check & 54.60 & 9.45 & 64.5 & $17.98(320.20)$ & 7.59 & 3.70 & 8.59 \\
\hline Pendimethaline @1.0 kg ha ${ }^{-1}$ & 119.78 & 21.13 & 110.0 & $12.63(160.20)$ & & & \\
\hline fbBispyricbac-Na@25.0 g ha ${ }^{-1}$ & & & & & 4.91 & 2.43 & 4.24 \\
\hline Bispyricbac-Na@25.0 g ha & 152.46 & 30.09 & 155.2 & 9.45 & & & \\
\hline${ }^{1} f b$ Carfentrazone @ $20.0 \mathrm{~g} \mathrm{ha}^{-1}$ & & & & $(90.20)$ & 3.77 & 2.07 & 3.83 \\
\hline Bispyricbac-Na@25.0 g ha ${ }^{-}$ & 151.62 & 29.53 & 151.5 & 9.50 & & & \\
\hline${ }^{1} f b$ Ethoxysulfuron @ $18.0 \mathrm{~g} \mathrm{ha}^{-1}$ & & & & $(91.70)$ & 3.89 & 2.08 & 3.88 \\
\hline Pendimethalin@1.0 kg ha ${ }^{-1}$ & 112.65 & 19.74 & 104.9 & $14.27(210.10)$ & 5.38 & 2.68 & 4.56 \\
\hline SEm \pm & 4.34 & 1.02 & 3.2 & 0.18 & 0.815 & 0.39 & 0.83 \\
\hline $\mathrm{CD}(\mathrm{P}=0.05)$ & 12.55 & 2.94 & 9.3 & 0.52 & 2.46 & 1.17 & 2.49 \\
\hline
\end{tabular}

